\title{
Impact of Climate Change on Human Infectious Diseases: Dengue
}

\author{
Amaury de Souza ${ }^{1 *}$ \\ https://orcid.org/0000-0001-8168-1482 \\ Marcel Carvalho Abreu ${ }^{2}$ \\ https://orcid.org/0000-0002-6457-421X
}

\section{José Francisco Oliveira-Júnior ${ }^{3}$ \\ https://orcid.org/0000-0002-6131-7605}

${ }^{1}$ Federal University of Mato Grosso do Sul, Institute of Physics, Campo Grande, MS, Brazil; ${ }^{2}$ Federal Rural University of Rio de Janeiro, Department of Environmental Sciences, Seropédica, Rio de Janeiro Brazil; ${ }^{3}$ Federal University of Alagoas, Institute of Atmospheric Sciences (ICAT), Maceió, Brazil.

Editor-in-Chief: Paulo Vitor Farago

Associate Editor: Andressa Novatski

Received: 2019.08.18; Accepted: 2020.12.18.

*Correspondence: amaury.de@uol.com.br; Tel.: +55-67-993248963 (A.S.)

\section{HIGHLIGHTS}

- Climate change affects human infectious disease via pathogen, host and transmission.

- Go beyond the empirical observation of the association between climate and health effect.

- Improve prediction of associated changes in infectious diseases at various scales.

- Health impacts can be controlled by taking certain proactive measures.

Abstract: Climate is considered an important factor in the temporal and spatial distribution of vector-borne diseases. Dengue transmission involves many factors: although it is not yet fully understood, climate is a critical factor as it facilitates risk analysis of epidemics. This study analyzed the effect of seasonal factors and the relationship between climate variables and dengue risk in the municipality of Campo Grande, from 2008 to 2018. Generalized linear models with negative binomial and Poisson distribution were used. The most appropriate model was the one with "minimum temperature" and "precipitation", both lagged by one month, controlled by "year". In this model, a $1^{\circ} \mathrm{C}$ rise in the minimum temperature of one month led to an increase in dengue cases the following month, while a $10 \mathrm{~mm}$ increase in precipitation led to an increase in dengue cases the following month.

Keywords: dengue; climate; temporal distribution.

\section{INTRODUCTION}

Responding to global change through the pursuit of sustainable development is a major challenge for human society [1,2]. Climate change can affect human health [3-6], especially when it comes to infectious diseases [7-9]. Three components are essential for most infectious diseases: an agent (or pathogen), a host (or vector), and transmission environment [7]. 
Some pathogens are vector-borne or require intermediate hosts to complete their life cycle. Appropriate weather conditions are necessary for the survival, reproduction, distribution and transmission of disease pathogens, vectors and hosts. Therefore, changes in climate or weather conditions can affect infectious diseases by affecting pathogens, vectors, hosts and their living environment $[7,10]$.

Studies have found that long-term climate warming tends to favor the geographic spread of various infectious diseases $[3,12,13]$ and that extreme weather events can help create opportunities for clustered disease outbreaks or outbreaks in nontraditional places and times [14]. Overall, climatic conditions restrict geographic and seasonal distributions of infectious diseases, and climate affects the timing and intensity of disease outbreaks $[10,15]$.

A climate of warming and instability is playing an increasingly important role in driving the global emergence, resurgence and redistribution of infectious diseases [16]. Many of the most common infectious diseases, particularly those transmitted by insects, are highly sensitive to climate variation [15,17]. New and resurgent vector-borne communicable diseases, including dengue, malaria, hantavirus, and cholera, are widely evident [18-20].

Dengue is an acute febrile disease caused by arboviruses (arthropod-borne viruses) of the Flaviviridae family, with female Aedes aegypti culicid mosquitoes as the vector. Tropical countries are the most heavily affected due to their environmental, climatic, and social conditions. Climate is an important factor in the temporal and spatial distribution of vector-transmitted diseases like dengue fever. Studies of climatic variables can improve knowledge and prediction of epidemic seasonality [21], because the vector-climate relationship is just as important as vector-human interaction.

Several authors have investigated the relationship between climatic variables and dengue fever, often using time-series analysis to describe temporal trends, to identify patterns, and even to make predictions. The variables used in these studies have been temperature, precipitation, relative humidity, wind velocity, and EI Niño Southern-Oscillation (ENSO) [22-30]. Studies have also evaluated dengue's relationship with socio-demographic and environmental variables in the municipality of Rio de Janeiro, Brazil, with a view to examining the effect of seasonal and annual factors on increases and decreases in dengue cases, as well as to make predictions [31-33].

Dengue incidence fluctuates with climatic conditions and is associated with increased temperature and rainfall, ENSO interferes with the action of meteorological systems, changing or intensifying rainfall and air temperatures in Brazil [34,30]. Such conditions favor an increase in the number of available breeding sites, as well as the vector's development, and thereby increase the probability of vector-human (and consequently human-virus) interaction. According to various studies, temperature has an impact on the population size, maturation period, blood-sucking activity, and survival rate of Aedes aegypti $[35,36,37,38]$. The relationship to precipitation depends on local characteristics and whether breeding sites are maintained predominantly by rain [22].

The present study aimed to analyze the effect of seasonal factors and how the climate variables "temperature", "precipitation" and "relative humidity" were related to the risk of dengue in the city of Campo Grande, MS, Brazil, from 2008 to 2018 and the Impact of climate change on number of dengue cases.

\section{MATERIAL AND METHODS}

Geographically, the municipality of Campo Grande is located near the Brazilian border with Paraguay and Bolivia. It is located at latitude $20^{\circ} 26^{\prime} 34^{\prime \prime}$ South and longitude $54^{\circ} 38^{\prime} 47^{\prime \prime}$ West. The climate of Campo Grande is classified as tropical with a dry season ("Aw", according to the Köppen-Geiger climate classification), indicating the coldest months (June and July) with an average compensated temperature of $18.6^{\circ} \mathrm{C}$, transition between the monsoon tropical ("Am", according to Köppen), the dry season tropical and the humid subtropical ("Cfa", according to Köppen). The thermal amplitude is relatively high due to the great influence of continentality, Campo Grande has quite variable temperatures during the year with two very well defined seasons: hot and humid in summer and less rainy and milder in winter. In winter months the temperature can drop considerably with sporadic and light frosts, on occasion the thermal sensation can reach below $0^{\circ} \mathrm{C}$.

The research used an ecological time series and analytical study, with a quantitative and descriptive approach. The data were obtained from a seconDCy source and correspond to the number of dengue cases (DC) reported in the Reported Diseases Information System (SINAN) (codes ICD-10 A90-A91), between 2008 and 2018. The number of cases was paid in each month of each year, being, therefore, the object of study (number of dengue cases per month). 
Meteorological data between 2008 and 2018 were also obtained from the Water Resources Monitoring Center (CEMTEC-MS). The meteorological data set was composed of monthly data on minimum, average and maximum temperature (Tmin, Tavg and Tmax), relative humidity (RU) and precipitation (Prec) of the Campo Grande city, Mato Grosso do Sul State.

Exploratory data analysis was performed using boxplots, time series decomposition and autocorrelation plots. The outcome variable was the number of dengue cases, and the independent variables were monthly average rainfall, monthly minimum and maximum temperatures. After exploratory analysis, cutoff points for average temperature were evaluated by generalized additive models [39].

Dengue risk was observed to increase up to $26^{\circ} \mathrm{C}$. According to the literature, the mosquito's optimal temperature is from $22^{\circ} \mathrm{C}$ to $26^{\circ} \mathrm{C}$, based on which the following variables were used: proportion of days in the month with mean temperature below $22^{\circ} \mathrm{C}$, which corresponds to $85 \%$ of the values observed; proportion of days in the month with mean temperature from $22^{\circ} \mathrm{C}$ to $26^{\circ} \mathrm{C}$, which corresponds to $87 \%$ of the values observed in this interval; and proportion of days in the month with mean temperature above $26^{\circ} \mathrm{C}$, which corresponds to $55 \%$ of the values observed [40-44].

The effect of climate variables on the number of reported cases was assessed using generalized linear models [45] with a logarithmic binding function for Poisson and negative binomial distribution. Time series are characterized by a sequence of data obtained at equal time intervals. The data used here refer to months, which do not have the same number of days, so compensation was employed in multiplying the population by the number of days in the month. Model fit was assessed by autocorrelation and residual normality test.

Analyzes were performed using the $\mathrm{R}$ software, version 2.10.1 (The R Foundation for Statistical Computing, Vienna, Austria; http://www.r-project.org). The models were compared with the Akaike Information Criterion (AIC), which is widely used to compare models.

\section{RESULTS}

The Anderson-DCling (AD) normality test was performed to verify the normality of the variables under study. Therefore, according to the results presented in Table 1, it is possible to observe the non-normality of the analyzed variables ( $p$-value $<0.001$ ). Since these are count data, the Poisson distribution was initially adjusted. However, the model adjustment provided residual deviance, indicating strong signs of overdispersion and evidence that meant that the adjustment was not adequate $(p<0.001)$.

Table 1. Statistical distribution of dependent and independent variables and Anderson-DCling (AD) normality test of the dengue variable in relation to the climatic variables between 2008 and 2018.

\begin{tabular}{lllllll}
\hline Statistic & $\mathbf{D C}$ & $\mathbf{T m i n}\left({ }^{\circ} \mathbf{C}\right)$ & $\mathbf{T m a x}\left({ }^{\circ} \mathbf{C}\right)$ & $\mathbf{T a v g}\left({ }^{\circ} \mathbf{C}\right)$ & $\mathbf{R H}(\%)$ & $\operatorname{Prec}(\mathbf{m m})$ \\
\hline Means & 15.050 & 18.430 & 30.640 & 24.540 & 65.960 & 117.030 \\
SD & 33.020 & 3.160 & 2.450 & 2.120 & 12.220 & 91.290 \\
Variance & 1090.270 & 9.980 & 5.980 & 4.510 & 149.300 & 8333.710 \\
CV $(\%)$ & 219.460 & 17.140 & 7.980 & 8.660 & 18.530 & 78.000 \\
Q1 & 2.000 & 16.350 & 29.300 & 22.780 & 60.830 & 40.400 \\
Median & 4.500 & 19.500 & 30.950 & 25.480 & 69.900 & 97.250 \\
Q3 & 11.000 & 21.000 & 31.780 & 26.230 & 73.900 & 166.930 \\
Minimum & 0.000 & 6.900 & 25.600 & 18.100 & 2.300 & 0.000 \\
Maximum & 229.000 & 24.300 & 38.300 & 28.050 & 81.400 & 476.200 \\
Skewness & 3.950 & -1.250 & 0.250 & -0.750 & -2.250 & 1.030 \\
Kurtosis & 17.730 & 1.920 & 0.730 & -0.480 & 8.110 & 1.240 \\
Statistics AD & 25.390 & 8.310 & 3.890 & 4.120 & 6.210 & 6.340 \\
P-value & $<0.001$ & $<0.001$ & $<0.001$ & $<0.001$ & $<0.001$ & $<0.001$ \\
$\mathrm{n}$ & 132.000 & 132.000 & 132.000 & 132.000 & 132.000 & 132.000 \\
\hline
\end{tabular}

SD = StanDCd derivation; CV = coefficient of variation; Q1 = First quantile; Q3 = Thyrth quantile; AD = Anderson-DCling; $\mathrm{P}$-valor $=$ Anderson-DCling $\mathrm{p}$ value; $\mathrm{n}=$ number of observations . 
The Figure 1 shows the box-plot analysis of the number of cases and the precipitation that occurred in the years of analysis, represented by lines. It is possible to observe a coincidence between the extreme values of dengue cases in months when precipitation was higher. From January to April, a greater number of cases and, invariably, greater rainfall were observed, especially extreme values. The relationship between dengue and rain has been reported [45].

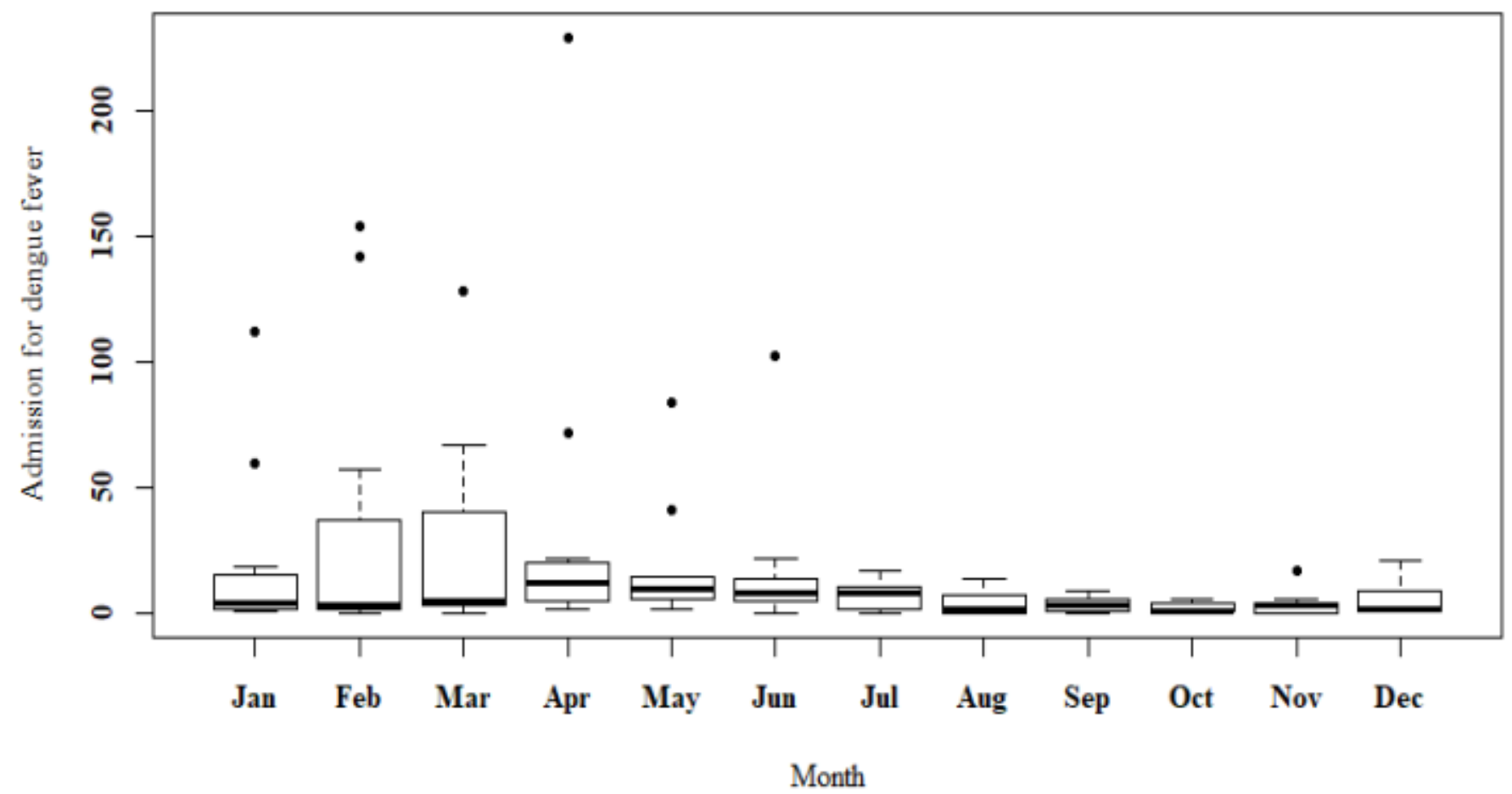

Figure 1. Box-plot analysis for the hospital admissions for dengue fever.

The Figure 2 shows the serie, sazonal, trend and remainder analysis for minimum (Tmin) and maximum (Tmax) and average air temperature (Tavg), relative humidity (RU), precipitation (Prec) in Campo Grande. The time series for the variables: minimum, average and maximum temperatures, precipitation and relative umidity in the month with mean temperature show sazonality and values below $22^{\circ} \mathrm{C}$, from $22^{\circ} \mathrm{C}$ to $26^{\circ} \mathrm{C}$, and above $26^{\circ} \mathrm{C}$ (Figure 3 ). There is certainly some seasonal variation in the number of for the hospital admissions for dengue fever per month which is related to the seasonality of the weather elements, according with Figure 3. 

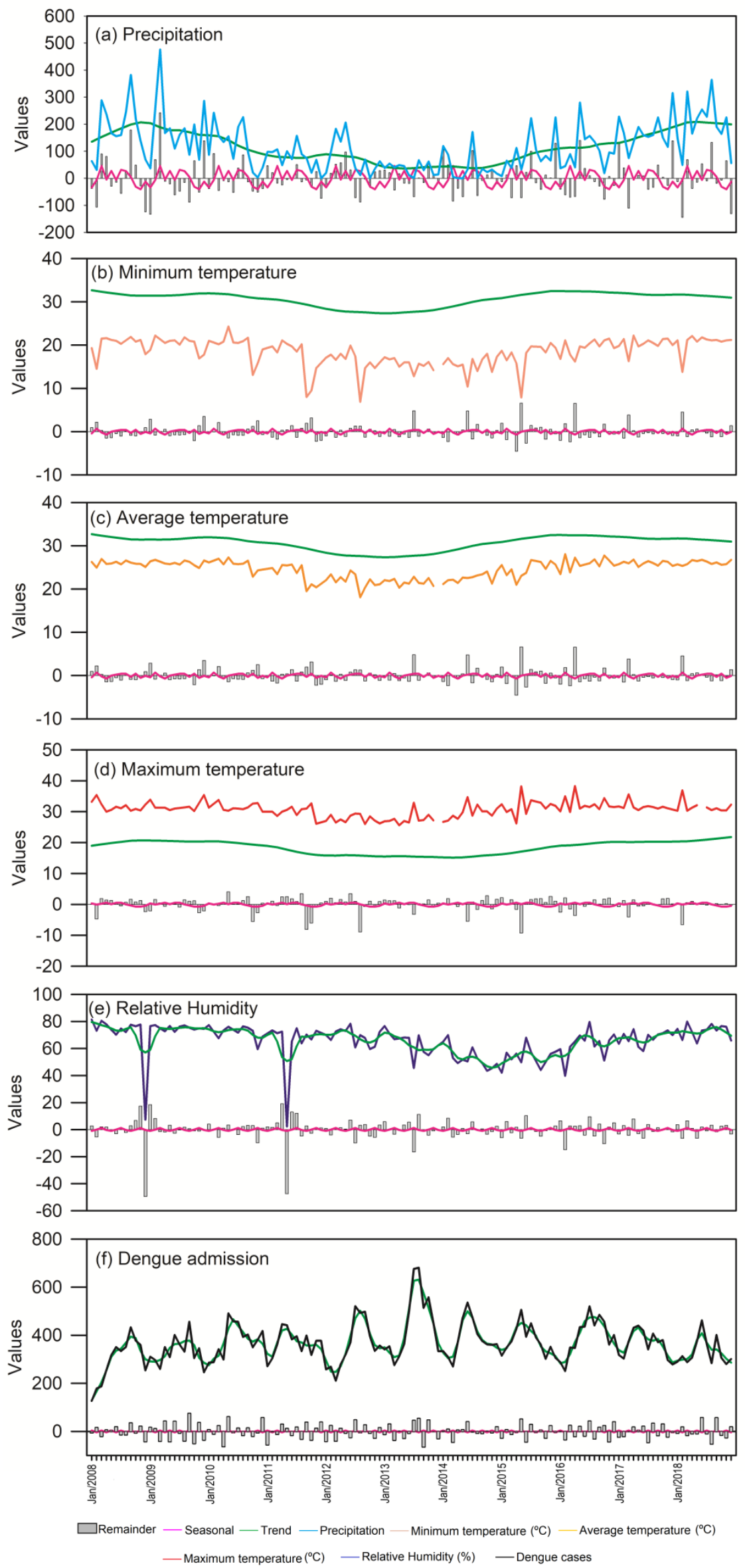

Figure 2. Seasonal, trend and remainder time series analysis for the minimum, average and maximum air temperature (c), relative humidity (d), precipitation (e) and DC (f) in Campo Grande, MS, 2008-2018. Legend: Tmin = minimum temperature; $\mathrm{Tavg}$ = avarege temperature; $\mathrm{Tmax}=$ maximum temperature; $\mathrm{RU}=$ relative umidity; Prec = precipitation; $\mathrm{DC}=$ number of hospital admissions for dengue. 


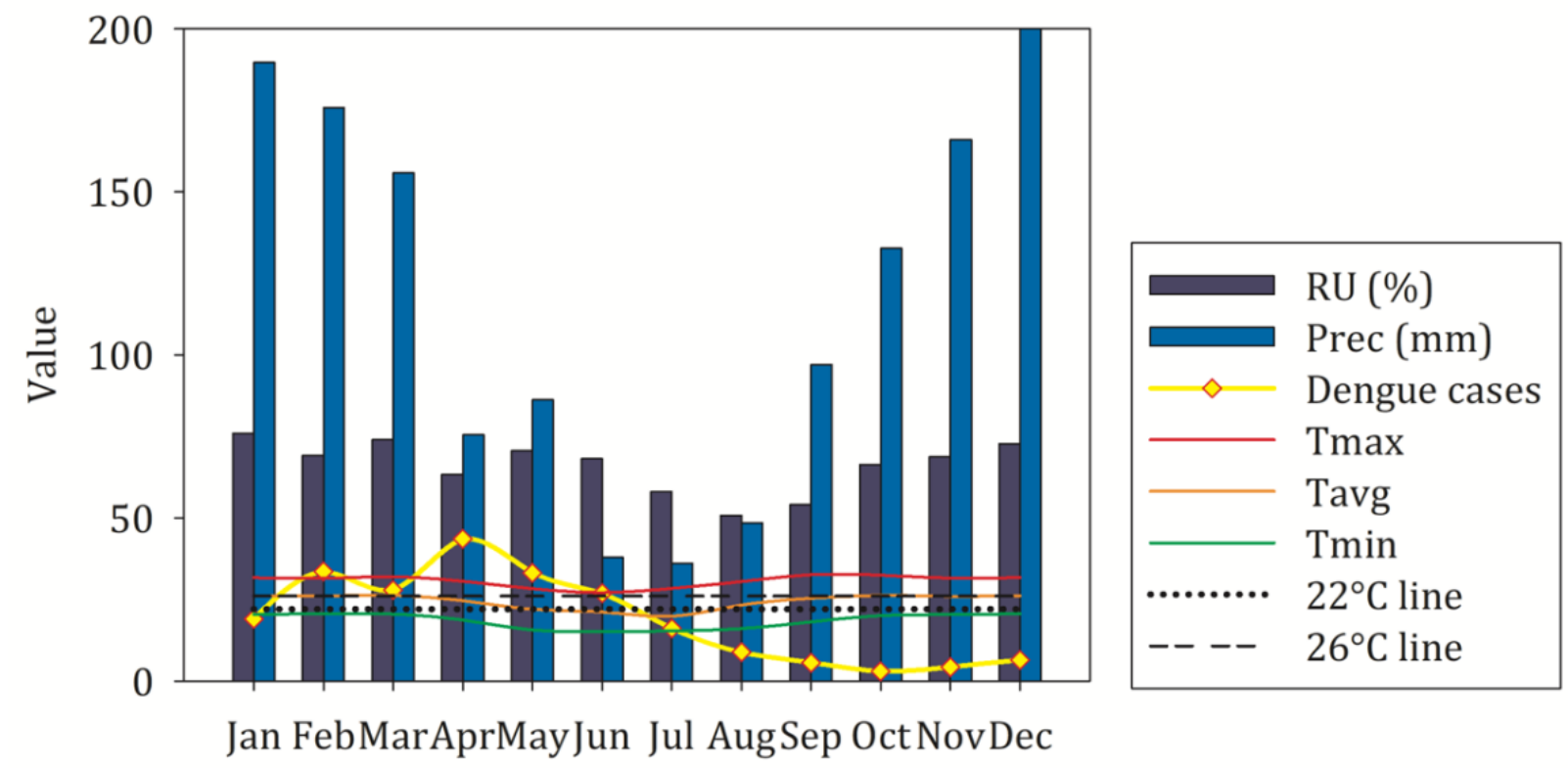

Figure 3. Monthly number of dengue cases and climatic variables for Campo Grande, MS. Tmax = maximum temperature $\left({ }^{\circ} \mathrm{C}\right)$; Tavg = average temperature $\left({ }^{\circ} \mathrm{C}\right)$; minimum temperature $\left({ }^{\circ} \mathrm{C}\right) ; \mathrm{RU}=$ relative humidity $(\%) ;$ Prec $=$ precipitation $(\mathrm{mm})$.

There are two well-defined seasons in Campo Grande, where from September/October to March is the rainy season and from April to August/September is the dry season. The relative humidity of the air follows the precipitation during the year. This analysis is important to verify the most appropriate periods for the reproduction of the Aedes egypty mosquito. Temperatures are lower in the dry seasons and higher in the rainy season. Only between May and July the average temperature is below $22^{\circ} \mathrm{C}$. Campo Grande can therefore be considered a region susceptible to dengue outbreaks. In general, the series of climatic variables showed seasonality, but not trends.

The figure 4 show the correlation between the DC and the climatic variables (panel a) and the variation of DC and climatic variables years of analysis. The between DC and climatic variables were, in general, negative correlation with low values $(|r|<0.50)$. It is possible to observe a delay in the response of the $D C$ in relation to precipitation, especially at the beginning of the rainy season. With the beginning of the rainy season in September/october, precipitation monthly totals start to increase, while the number of DC has increased effectively in January.

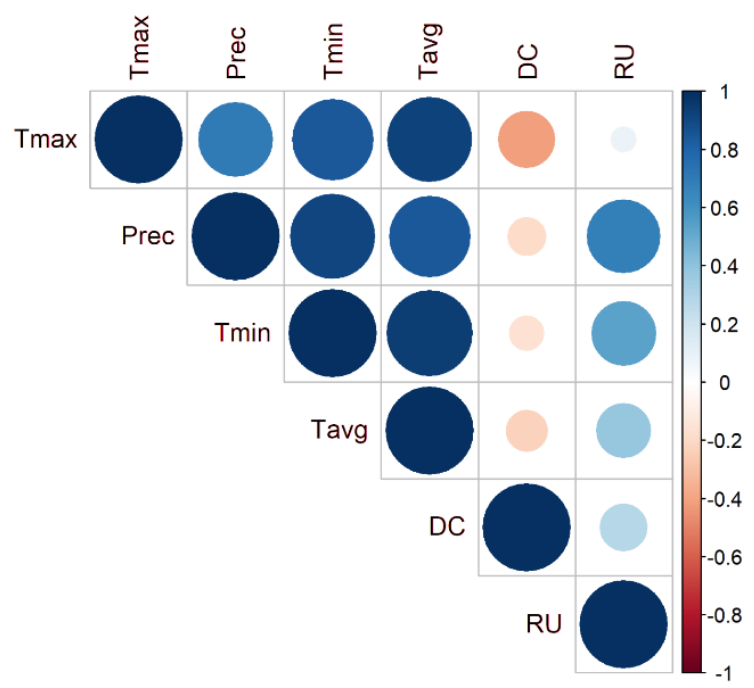

Figure 4. Analysis of the correlation of the dengue and the climatic variables. Tmax = maximum temperature $\left({ }^{\circ} \mathrm{C}\right) ;$ Tavg $=$ average temperature $\left({ }^{\circ} \mathrm{C}\right)$; minimum temperature $\left({ }^{\circ} \mathrm{C}\right) ; \mathrm{RU}=$ relative humidity $(\%)$; Prec $=$ precipitation $(\mathrm{mm}) ; \mathrm{DC}=$ dengue cases. 
Figure 5 shows the time series for dengue cases and the series as estimated, which managed to detect the epidemic years, although underestimating the major epidemics and overestimating the number of dengue cases in the following year.

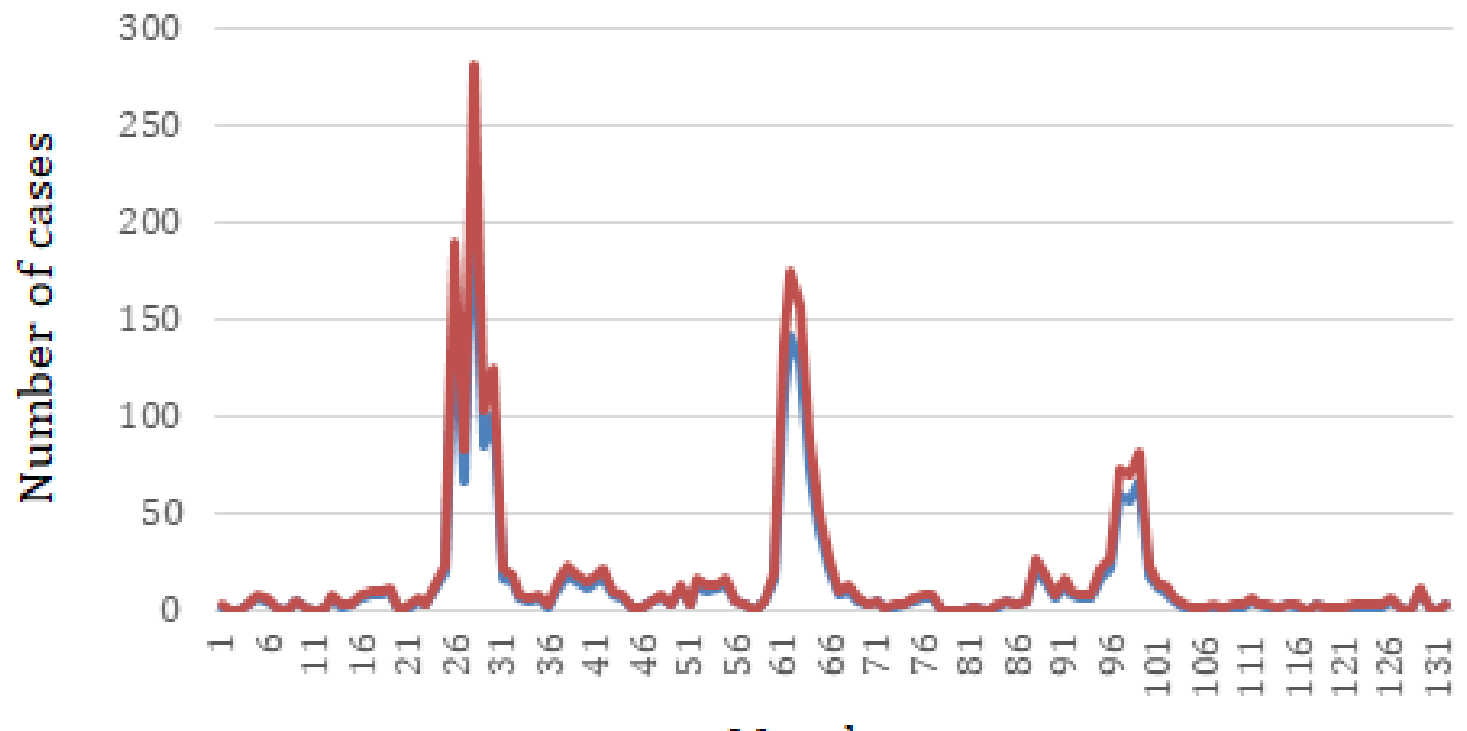

Months

Hospital admissions: observed $(-)$ and estimates $(-)$

Figure 5. Times series of dengue cases and series estimed.

Table 2 and Figure 5 show the main statistics described for the dependent and independent variables, highlighting the discrepancy between the mean and variance values, values that should have equal or close values in order to be able to adapt to the assumptions of the Poisson model. Thus, the results presented indicate a probable overdispersion of dengue cases in the municipality under study, that is, a variance higher than the average. As for the shape measures of the data distribution, the values of asymmetry and kurtosis suggest that the data are well dispersed around their average value and have a low correlation index between the variables.

Analysis of the distribution of cases showed that most cases were concentrated in the first half of the year, especially from January to April, highlighting the known seasonality of dengue. The average annual temperatures for the period were $24,5^{\circ} \mathrm{C}$, for the minimum monthly average temperature of $18^{\circ} \mathrm{C}$ and for the maximum monthly average temperature of $31^{\circ} \mathrm{C}$. The monthly accumulated precipitation in the period ranged from 36 to $203 \mathrm{~mm}$, with a monthly average of $117 \mathrm{~mm}$.

As the data are overdispersed (sample mean of 15, stanDCd deviation of 33 , a coefficient of variation of 219, minimum of zero and maximum of 229 for a number of observations of 132), the comparison of the AIC of the models showed that the negative binomial distribution was a better choice than the Poisson distribution. The models were initially equipped with only one variable; in these, the variable "proportion of days with temperature from $22^{\circ} \mathrm{C}$ to $26^{\circ} \mathrm{C}$ " was not significant, even when lagged, while precipitation was significant only in relation to the number of cases when lagged in one month. The other variables were significant with lags of up to two months.

On the basis of this initial analysis, all the models contained the variable precipitation, and then the inclusion of temperature-related variables was evaluated. Residuals analysis of the models showed that a time structure persisted; accordingly, an annual effect was incorporated into the model. Introduction of this variable improved both auto-correlation of residuals and model fit.

Table 2 shows the estimated relative risk (RR), 95\% confidence intervals (95\% ICI), and AIC for the fitted models. The RR for the variable "precipitation" varies little between the models. Concerning the AIC criterion for comparing models, the model with the best fit was the one which (after controlling for the variable "year") used the variables "minimum temperature" and "precipitation", both lagged by one month. In that model, a one-degree rise in temperature in a month led to a $45 \%$ increase in dengue cases in the following month, 
while a $10 \mathrm{~mm}$ increase in precipitation led to a $6 \%$ increase in dengue cases in the following month. These results are similar to those founded by [43] to Rio de Janeiro. Models with the variables "mean temperature" and "maximum temperature" presented similar results.

Table 2. Relative risk (RR), $95 \%$ confidence intervals (95\% IC), and Akaike Information Criterio (AIC) of the proposed models for the relationship between dengue transmission and meteorological variables, Campo Grande, MS, Brazil, 2008-2018.

\begin{tabular}{|c|c|c|c|c|}
\hline Models & Variables lagged by 1 month & $\mathbf{R R}$ & $95 \%$ IC & AIC \\
\hline \multirow[t]{2}{*}{1} & Minimum temperature & 1.324 & $1.305-1.398$ & 1.468 \\
\hline & Precipitation & 1.002 & $0.951-1.073$ & \\
\hline \multirow[t]{2}{*}{2} & Proportion of day with temperature $>26^{\circ} \mathrm{C}$ & 1.167 & $1.108-1.121$ & 1.483 \\
\hline & Precipitation & 1.003 & $0.952-1.076$ & \\
\hline \multirow[t]{2}{*}{3} & Proportion of day with temperature $<22^{\circ} \mathrm{C}$ & 0.912 & $0.866-1.079$ & 1.496 \\
\hline & Precipitation & 1.003 & 0.953-1.053 & \\
\hline
\end{tabular}

\section{DISCUSSION}

Several studies have reported a positive association between minimum temperature lagged by one month and dengue incidence [10, 24, 33, 46, 47]. Minimum temperature is thus a critical limiting factor in the development and maintenance of the vector population. Replication of the virus and maturation periods in the insect (extrinsic period) are shortened by increased temperature $[40,48,49]$, while decreased virus incubation time increases the likelihood that the vector will live long enough to transmit the virus, significantly boosting the magnitude of the epidemics.

Studies have shown that Aedes aegypti, the vector for dengue in the Americas, ceases to feed when temperature falls below $17^{\circ} \mathrm{C}$, and that the virus is not amplified in the vector when temperature falls below $18^{\circ} \mathrm{C}$, while the threshold survival temperature for the dengue virus has been estimated at $11.9^{\circ} \mathrm{C}[40,50$, 51]. Thus, at very low temperatures the virus develops more slowly, and the mosquito does not live long enough to become infectious and transmit the virus [52]. Accordingly, analysis of minimum temperatures affords a better understanding of dengue epidemics. This study showed a small (but significant) coefficient for the relationship between dengue cases and precipitation. Studies in the literature on the correlation between rainfall and dengue are contradictory, because the relationship depends on local characteristics [22, 53].

Analysis of Model 3 shows that a unit increase in the proportion of days in the month when the mean temperature falls below $22^{\circ} \mathrm{C}$ led to an $9 \%$ decrease in the number of dengue cases in the following month, corroborating reports by other authors, because the vector's feeding rate declines at lower temperatures (as does the viral transmission rate, consequently [53,59].

According to Model 2, which incorporates temperature above $26^{\circ} \mathrm{C}$, a unit increase in the proportion of days in the month when mean temperature is above $26^{\circ} \mathrm{C}$ leads to a $16 \%$ increase in dengue cases in the following month. That result was expected, because studies have found an association between dengue risk and temperatures above $26^{\circ} \mathrm{C}$, with temperatures from $21^{\circ} \mathrm{C}$ to $29^{\circ} \mathrm{C}$ favoring the development of Aedes aegypti, and from $22^{\circ} \mathrm{C}$ to $30^{\circ} \mathrm{C}$, the longevity and fertility of the adults [23, 55].

These results are important because they demonstrate the need to test the best models, since for each region, the results may be different. For the city of Rio de Janeiro, the best adjustment was controlled by indicative variables of the year, which show the minimum and minimum temperature variations, and with a reduction of one month. This is because at low temperatures they prevent the development of the Aedes aegypti mosquito [43]. In Can Tho (Mekong, Vietnam), [56] founded that the relative humidity was the most important meteorological predictor for dengue hospitalizations. 


\section{Climate change and disease transmission}

Many studies have proven that climate variables and weather conditions can affect disease transmission, despite some uncertainty about specific mechanisms. This impact may be direct, as changes in weather conditions may alter disease transmission, directly influencing pathogen viability. It may be indirect if a change in transmission routes results from human and vector/host response behaviors to climate change.

Temperature change alone or in conjunction with other variable changes, such as rain, can alter disease transmission. Climate change can affect the transmission of infectious diseases by changing the contact patterns of human-pathogen, human-vector or human-host.

Climate variation plays an important role in shaping the activity patterns and behaviors of humans and other hosts, such as seasonal occupation, migration, winter-summer lifestyles, and physical exercise ${ }^{[57]}$. These, in turn, can significantly influence the patterns of disease transmission [15].

Climate change can undermine human immunity and susceptibility to disease, thereby affecting the transmission of disease. This can lead to ecosystem degradation, which could possibly put pressure on agricultural productivity, causing problems such as crop failure, malnutrition, famine, increased population displacement, and resource conflict. These pressures may contribute to increased human susceptibility to infectious diseases.

\section{Societal response and human factor}

It is essential to recognize that social and economic factors play a significant role in predicting the changing risk for infectious diseases caused by climate change $[10,58,59]$. Some population and regions are more vulnerable to the elevated risks due to their lack of the ability to effectively respond to the stresses and challenges imposed by climate change [60-62]. Levels of vulnerability are partly a function of the programs and measures that are in place to reduce burdens of climate-sensitive health determinants and outcomes, and partly a result of the success of traditional public-health practices, including access to safe water and improved sanitation, and biosecurity and surveillance programs to identify and respond to infectious diseases outbreaks [62-65].

A society's vulnerability to climate change induced health risk of infectious diseases is further related to its existing public health system and infrastructure. Developing countries tend to be more sensitive to an elevated health risk caused by climate change due to the lack of resources and capabilities for their public health system to effectively respond to the various challenges.

Climate change results in variations in weather conditions and patterns of extreme weather events. The health effects of climate change (including changes in climate variables and extreme weather events) on human infectious diseases are imposed through impacts on pathogens, hosts/vectors, and disease transmission. First, a series of infectious diseases is spatially and temporally restricted by climatic variables. Changes of climate variables in spatial and/or temporal scales will affect the development, survival, reproduction, and livability of disease pathogens, hosts, and their interaction with human beings. Second, sudden and dramatic changes in weather conditions due to extreme weather events and meteorological hazards have profound effects on many infectious diseases. Due to our incomplete knowledge to some of these extreme weather events, being able to accurately predict their patterns and their health impacts remains challenging. Last, extreme weather, including large-scale extreme weather events and meteorological hazards, often involves combined shifts of several climate variables, making it more complicated to predict the implications for disease pathogens, hosts, and transmission.

Humans are more than passive recipients of climate change induced health effects. We can play a significant and active role by adopting proactive adaptation measures in order to control and alleviate the negative health impacts of climate change. First, the magnitude of changes in climate variables varies across the globe, posing more challenges and stresses for some societies than others. Regional specific projection of climate change induced health implications on infectious diseases is necessary. Second, given the same magnitude of climate change, some population groups and areas are more vulnerable to the elevated risks due to their lack of the ability and resources to effectively respond to the stresses and challenges. Recognizing that infectious diseases do not confine themselves within a vulnerable population group, developed countries and capable societies should work together with developing countries and less capable societies to reduce their vulnerability to climate change induced health risks. Third, human vulnerability to the changing risks for infectious diseases may be altered through proper adaptation measures. One example of such is to continuously improve public health programs and to timely (re-) allocate financial and health care resources following scientific projection of spatial-temporal changes in health risk for human infectious diseases. 
These data regarding the association of dengue cases and climatic variables in Campo Grande, MS, corroborate the study by [66], who highlighted the relationship between dengue cases and air temperature (monthly average) and relative air humidity. In relation to temperature, in Cuiabá, MT, between August 2004 and August 2005, one of the hottest capitals in the country (maximum average around $31^{\circ} \mathrm{C}$ ), the significant correlation with the maximum temperature, average and minimal [67]. In Teresina, PI, from 2002 to 2006, there was also a strong positive correlation between the incidence of dengue with precipitation and temperature, particularly in the first half of each year [68]. In the municipality of Rio de Janeiro, RJ, between 2001 and 2009, an increase of one degree in minimum temperature in one month generated a $45 \%$ increase in the number of dengue cases in the following month [43].

In Campo Grande in the period from 2008 to 2018, the temperatures did not vary considerably, and this fact may not be relevant for the development of the population of the mosquito that transmits dengue. The ideal temperature for the development of this ecological agent varies from $22^{\circ} \mathrm{C}$ to $26^{\circ} \mathrm{C}$, which demonstrates that high temperatures are not always related to the presence of the dengue vector [69]. Similar results were found in São Sebastião, SP, where, between 2001 and 2002, there was no association between the values of average monthly temperature, average monthly rainfall and number of dengue cases [34].

In line with the present study, in Cascavel, PR, between the years 2007 to 2011, a study identified that, in the period when the number of cases presented was greater, the relative humidity of the air was in an average level of $77 \%$ to $80 \%$. As for the smallest number of cases, this variable was between $67 \%$ and $72 \%$. Thus, the highest occurrence of dengue in the months of January, February and March is related, since the relative humidity of the air at levels above $70 \%$ favors the proliferation of the mosquito and its development [70].

In João Pessoa, PB, dengue had a higher incidence in the summer months, due to high temperature and humidity, and, in the autumn, due to rains. In the municipality of Rio de Janeiro in 2005, there was no statistically significant difference between the dry and rainy periods, with the seasonality effect being described as low or absent in most of the analyzed reservoirs [71].

In Rondonópolis, MT, there was no significant association between dengue cases and rainfall [72]. The relationship between the levels of this variable and dengue cases changes according to the place of study. In Boa Vista, RO, the correlation between the number of reported cases and the meteorological variables was not found, presenting a different pattern each year, highlighting the existence of case peaks in both the rainy and dry periods [21], in João Pessoa, PB, between 2007 and 2011, there was a greater number of records in the period in which there are higher precipitation values, corresponding to $85 \%$ of the notified cases [73], as well as, between 2007 and 2012, in Recife, PE, 1,844 cases of dengue were confirmed correlated to a pluviometric accumulation [74].

The pluviometric indexes were also not significant for the occurrence of dengue in the city of Rio de Janeiro, RJ between the years 1986-2003. As the period of greatest risk for increasing the number of cases of the disease, the hot and dry summers, the average minimum temperature above ${ }^{\circ} 2^{\circ} \mathrm{C}$, mainly in the first quarter of the analyzed period and the volume of rain below 200 were considered $\mathrm{mm} / \mathrm{month}$ [75].

\section{CONCLUSION}

The highest number of hospital admissions for dengue fever occurs between the months of January and April, influenced by the highest minimum temperatures and the highest total rainfall that start between the months of November and March.

Dengue transmission involves a number of factors, including the impact of climate, whose role is not yet fully understood. Clarifying the role of climate is critical because it facilitates epidemic risk analysis and aids preventive efforts. This study proposed a model to examine dengue time series, in which mean, maximum and minimum temperature, relative humidity and precipitation were statistically associated with the number of cases, while the minimum lagged one-month temperature proved to be the most important explanatory factor strong for the number of cases of dengue cases.

Funding: This research received no external funding.

Acknowledgments: The authors would like to thank their Universities for their support.

Conflicts of Interest: The authors declare no conflicts of interest.

Database declaration / Data availability: The climate database is in the public domain and is available at: https://www.cemtec.ms.gov.br/ and the hospital admissions database is available at http://www2.datasus.gov.br/DATASUS/index.php?area=02 
Ethical considerations: The present study is based on seconDCy data, of public access, that do not constrain groups of populations and / or individuals in presenting the results found, ensuring the confidentiality of the information collected. Therefore, ethical aspects of research with human beings were respected, according to Resolution no. 466/2012 [76].

\section{REFERENCES}

1. Weng, Q.H., Xu, B., Hu, X. F., Liu, H. Use of earth observation data for applications in public health. Geocarto Int. 2013, 29: 3-16.

2. Yang, J., Gong, P., Fu, R., Zhang, M.H., Chen, J.M., Liang, S.L., Xu, B.,Shi, J.C.,Dickinson, R. The role of satellite remote sensing in climate change studies. Nat. Clim. Chang. 2013, 3: 875-883.

3. Epstein, P. R. Climate and Health. Science.1999, 285:347-348.

4. Kovats, R. S., Menne, B., McMichael, A. J., Corvalan, C., Bertollini, R. Climate Change and Human Health: Impact and Adaptation. World Health Organization - WHO. 2000.

5. Costello, A., Abbas, M., Allen, A., Ball, S., Bell, S., et al. Managing the health effects of climate change. The Lancet. 2009, 373:1773-1964.

6. Willox, A.C., Stephenson, E., Allen, J., Bourque, F., Drossos, A., Elgarøy, S., Kral, M.J., Mauro, I., Moses, J., Pearce, T. Examining relationships between climate change and mental health in the Circumpolar North. Reg. Environ. Chang. 2015, 15: 169-182.

7. Epstein, P.R. Climate change and emerging infectious diseases. Microbes Infect. 2001a 3: 747-754.

8. Altizer, S., Ostfeld, R. S., Johnson, P.T.J., Kutz, S., Harvell, C.D. Climate change and infectious diseases: from evidence to a predictive framework. Science. 2013, 341: 514-519.

9. Bouzid,M.,Colón-González,F.J.,Lung,T.,Lake,I.R.,Hunter,P.R. Climate change and the emergence of vector-borne diseases in Europe: case study of dengue fever. BMC Public Health. 2014, 14:2-12.

10. Wu, X.X., Tian,H.Y., Zhou,S., Chen,L.F.,Xu,B. Impact of climate change on human infectious diseases: Empirical evidence and human adaptation. Env. Int. 2016, 86:14-23.

11. Epstein, P. R., Diaz, H. F., Elias, S., Grabherr, G., Graham, N.E., et al.Biological and physical signs of climate change: focus on mosquito-borne diseases. Bull.Am.Meteorol.Soc. 1998, 79: 409-417.

12. Rodó, X., Pascual, M., Doblas Reyes, F. J., Gershunov, A., Stone, D. A., Giorgi, F., Hudson , P. J., Kinter, J., Rodríguez-Arias, M. A., Stenseth, N. C. Climate change and infectious diseases: can we meet the needs for better prediction? Clim.Chang. 2013, 118: 625-640.

13. Ostfeld, R.S., Brunner, J.L. Climate change and Ixodes tick-borne diseases of humans. Philos.Trans.R.Soc.Lond.Ser.BBiol.Sci. 2015, 370:140-151.

14. Epstein, P.R. Is global warming harm ful to health? Sci.Am. 2000, 283: 50-57.

15. Kuhn, K., Campbell Lendrum, D., Haines, A., Cox, J. Using Climate to Predict Infectious Disease Epidemics. World Health Organization - WHO, Geneva, Switzerland. 2005.

16. McMichael, A. J., Haines, A., Slooff, R., Kovats, S. Climate Change and Human Health. An Assessment by a Task Group on Behalf of the World Health Organization the World Meteorological Organization and the United Nations Environment Programme. World Health Organization - WHO,Geneva,Switzerland.1996.

17. Tian, H. Y., Zhou, S., Dong, L., Van Boeckel, T. P., Cui, Y. J., Wu, Y. R., Cazelles, B.,Huang, S. Q., Yang, R. F., Grenfell, B. T., Xu, B. Avian influenzaH5N1 viral and bird migration networks in Asia. Proc. Natl. Acad. Sci. U.S.A. 2015a, 112:172-177.

18. Watson, R.T., Zinyowera, M.C., Moss, R.H., Basher, R.E., Beniston, M., Canziani, O.F., Diaz, S.M.,Dokken, D.J. et al. The Regional Impacts of Climate Change: An Assessment of Vulnerability. IPCC Special Report, Working Group II Published for the Intergovernmental Panel on Climate Change: IPCC, 1997.

19. Tian, H.Y., Bi, P., Cazelles, B., Zhou, S., Huang, S. Q., Yang, J., Pei, Y., Wu ,X. X., Fu ,S. H., Tong, S. L., Wang, H. D., Xu, B. How environmental conditions impact mosquito ecology and Japanese encephalitis: an ecoepidemiological approach. Environ. Int. 2015, 79:17-24.

20. Yu, P., Tian, H., Ma, C., Ma, C., Wei, J., Lu, X., Wang, Z., Zhou, S., Li, S., Dong, J. Hanta virus infection in rodents and hemorrhagic fever with renal syndrome in Shaanxi Province, China, 1984-2012. Epidemiol. Infect. 2015, 143:405-411.

21. Rosa Freitas, M. G., Schreiber, K. V., Tsouris, P., Weimann, E. T. S., Luitgards Moura, J. F. Associations between dengue and combinations of weather factors in acity in the Brazilian Amazon. Rev. Panam. Salud Pública. 2006, 20:256-267.

22. Wu, P. C., Guo, H. R., Lung, S. C., Lin, C. Y., Su, H. J. Weather as an effective predictor for occurrence of dengue fever in Taiwan. Acta Trop. 2007, 103:50-57.

23. Hii, Y. L., Rocklöv, J.,Ng,N.,Tang,C.S.,Pang,F.Y.,Sauerborn, R. Climate variability and increase in intensity and magnitude of dengue incidence in Singapore. Glob. Health Action. 2009,2:1-9. 
24. Liang, L., Hualiang, L., Linwei, T., Weizhong, Y., Jimin, S., Qiyong, L. Time series analysis of dengue fever and weather in Guangzhou, China. BMC Public Health. 2009, 9:1-5.

25. Gasparrini, A., Armstrong, B. Time series analysis on the health effects of temperature: advancements and limitations. Environ. Res. 2010, 110:633-638.

26. Thail, K. T. D., Anders, K. L. The role of climate variability and change in the transmission dynamics and geographic distribution of dengue. Exp. Biol. Med. 2011, 236:944-954.

27. Cassab, A., Morales, V., Mattar, S. Factores climáticos y casos de dengue em Montería, Colombia, 2003/2008. Rev. Salud Pública. 2011,13:115-128.

28. Earnest, A., Tan, S. B., Wilder Smith, A. Meteorological factors and El Niño Southern Oscillation are independently associated with dengue infections. Epidemiol. Infect. 2012,140:1244-1251.

29. Correia Filho, W. L. F. Influence of meteorological variables on dengue incidence in the municipality of Arapiraca, Alagoas, Brazil. Rev. Soc. Bras. Med. Trop. 2017, 50:309-314.

30. Oliveira Júnior, J. F.,'Gois, G., Silva, E. B., Teodoro, P. E., Johann, J., Silva Junior, C. A. Non parametric tests, multivariate analysis and descriptive and exploratory statistics applied to reported dengue cases in Brazil. Environ. Monit. Ass. 2019, 191: 473-491.

31. Ferreira, G. S. Análise espaço-temporal da distribuição dos casos de dengue na cidade do Rio de Janeiro no período de 1986 a 2002 [MastersThesis].Rio de Janeiro,2004:Universidade Federal do Rio de Janeiro.

32. Teixeira, T. R. A. Análise espacial-temporal da dengue no contexto socioambiental do Município do Rio de Janeiro, 1996-2006 [MastersThesis]. Rio de Janeiro: Escola Nacional de Saúde Pública Sergio Arouca, Fundação Oswaldo Cruz, 2009.

33. Descloux, E., Mangeas, M., Menkes, C. E., Lengaigne, M.,Leroy, A.,Tehei,T.,et al. Climate base dmodels for understanding and forecasting dengue epidemics. PLoS Negl.Trop. Dis. 2012, 6:e1470.

34. Ribeiro, A. F., Marques, G., Voltolini, J. C., Condino, M. L. F. Associação entre incidência de dengue e variáveis climáticas. Rev. Saúde Púb. 2006,40:671-678.

35. Li, C. F., Lim, T. W., Han, L. L., Fang, R. Rainfall, abundance of Aedes aegypti and dengue infection in Selangor, Malaysia. Southeast Asian J. Trop. Med. Public Health. 1985, 16: 560-568.

36. Jetten, T. H., Focks, D. A. Potential changes in the distribution of dengue transmission under climate warming. Am. J.Trop. Med. Hyg.1997, 57:285-97.

37. Halstead, S. B. Dengue. The Lancet. 2007,370:1644-52.

38. Chen, S. C., Hsieh, M. H. Modeling the transmission dynamics of dengue fever: implications of temperature effects. Sci. Total Environ., 2012, 431:385-391.

39. Wood, S.N. Generalized additive models:an introduction with R. Boca Raton:Chapman \& Hall/CRC,2006.

40. Watts, D.M.,Burke, D.S.,Harrison,B.A.,Whitmire,R.E.,Nisalak,A. Effect of temperature on the vector efficiency of Aedes aegypti for dengue 2 virus. Am. J. Trop. Med. Hyg.1987, 36:143-52.

41. Carrington, L.B., Armijos, M.V.,Lambrechts, L.,Scott,T.W. Fluctuations at low mean temperatures accelerate dengue virus transmission by Aedes aegypti. PLoS Negl.Trop. Dis. 2013,7:e2190.

42. Lambrechts, L., Paaijmans, K., Fansiri, T., Carrington, L. B., Kramer, L.,Thomas, M. B.,Scott,T.W.Impact of daily temperature fluctuations on dengue virus transmission by Aedes aegypti. Proceedings of the National Academy of Sciences of the United States of America. 2011, 108:7460-7465.

43. Gomes, A. F.,Nobre, A.A.,Cruz,O.G. Temporal analysis of the relationship between dengue and meteorological variables in the city of Rio de Janeiro, Brazil,2001-2009.Cad. Saúde Pub. 2012, 28:2189-2197.

44. Tjaden, N. B., Margarete, T., Fischer, D., Beierkuhnlein.Extrinsic Incubation Period of Dengue:Knowledge, Backlog,and Applications of Temperature Dependence. PLoS Negl.Trop. Dis., 2013, 7:e512.

45. McCullagh, P., Nelder, J. A. Generalized linear models. London:ChapmanandHall, 1989.

46. Yasuno, M., Tonn, R.J. A study of biting habits of Aedesa egypti in Bangkok,Thailand.Bull. World Health Organ.1970, 43:319-325.

47. Hurtado Díaz, M., Riojas Rodríguez, H., Rothenberg, S. J.,Gomez Dantés, H., Cifuentes,E. Shortcommunication:impact of climate variability on the incidence of dengue in Mexico. Trop. Med. Int. Health. 2007,12:1327-1337.

48. Mendonça, M. Febre amarela silvestre. Rio de Janeiro:Gráfica Olympia,1941.

49. Reiter, P. Global warming and mosquito-borne disease in USA. The Lancet.1996, 348:622-632.

50. Christy, J. R., Clarke, R. A., Gruza, G. V., Jouzel, J., Mann, M. E., Oerlemans, J., et al. Observed climate variability and change. In: McCarthy,J. J., Canziani, O. F., Leary, N. A., Dokken, D. J., White, K. S.,editors. Climate change 2001: impacts, adaptation, and vulnerability. Cambridge: Cambridge University Press, 2001.p.99-181.

51. Reed, W., Carroll, J., Agramonte, A. Experimental yellow fever, 1901. MilMed. 2001,166:55-60. 
52. Hales, S., Wet, N., Maindonald, J., Woodward, A. Potential effect of population and climate changes on global distribution of dengue fever: an empirical model. The Lancet. 2002, 360:830-840.

53. Gubler, D. J., Reiter, P., Ebi, K. L., Yap, W., Nasci, R., Patz, J. A. Climate variability and change in the United States:potential impacts on vector-androdent-borne diseases. Environ. Health Perspect. 2001,109:223-33.

54. Honório, N. A., Codeço, C. T., Alves, F. C., Magalhães, M. Temporal distribution of Aedesa egypti in different districts of Rio de Janeiro, Brazil, measured by two types of traps. J. Med. Entomol. 2009,46:1001-1114.

55. Beserra, E. B., Castro Júnior,F. P., Santos, J. W., Santos,T. S.,Fernandes,C. R. M. Biologia e exigências térmicas de Aedesaegypti(L.) (Diptera:Culicidae) provenientes de quatro regiões bioclimáticas da Paraíba. Neotrop. Entomol. 2006, 35:853-60.

56. Toai, N.P.,Chinh,D.V.,Huy,N.N.,Vittor, A.Y. Associations between meteorological variables, vector indices and dengue hospitalizations in CanTho,Vietnam:afieldsurvey.BioRxiv,2019.

57. Viboud, C., Pakdaman, K., Boelle, P. Y., Wilson, M. L., Myers, M. F., Valleron, A. J., Flahault, A. Association of influenza epidemics with global climate variability. Eur. J. Epidemiol. 2004,19:1055-1059.

58. Semenza, J. C., Menne, B. Climate change and infectious diseases in Europe. The Lancet Infect.Dis.2009, 9:365375.

59. Xu, B., Jin, Z.Y., Jiang, Z.B., Guo, J.P., Timberlake, M.,X.L.Ma,.Climatological and geographical impacts on global pandemic of influenza $\mathrm{A}(\mathrm{H} 1 \mathrm{~N} 1)$ Q.Weng(Ed.), Global Urban Monitoring and Assessment through Earth Observation, Taylor \& Francis/CRCPress, Florida,U.S.A, 2014.

60. Wei, T., Yang, S. L., Moore, J. C., Shi, P. J., Cui, X. F, Duan, Q.Y., Xu, B., Dai, Y.J., Yuan, W.P., Wei, X. Developed and developing world responsibilities for historical climate change and $\mathrm{CO}_{2}$ mitigation. Proc. Natl. Acad. Sci. 2012, 109:12911-12915.

61. Wang, Y., Jiang, Z. B., Jin, Z. Y., Tan, H. Y., Xu, B. Risk factors for infectious diseases in backyard poultry farms in the Poyang lake area, China. PLoS One. 2013,8:67366.

62. Li, R., Jiang, Z. B., Xu, B. Global spatiotemporal and genetic footprint of the H5N1 avian influenza virus. Int. J. Health Geogr. 2014, 13:14.

63. Confalonieri, U., Menne, B., Akhtar, R., Ebi, K. L.,Hauengue, M., Kovats, R.S., Revich, B., Woodward, A. Humanhealth .M. L. Parry, O. F. Canziani, J. P. Palutikof, P. J. vanderLinden, C. E. Hanson(Eds.), Human Health Climate Change 2007: Impacts, Adaptation and Vulnerability, IPCC, Cambridge, UK, 2007.

64. Bai, L., Woodward, A., Liu, Q. Temperature and mortality on the roof of the world: a time series analysis in three Tibetan counties. Sci.Total Environ. 2014, 485: 41-48.

65. Jiang, Q., Zhou,J., Jiang, Z.B., Xul, B. Identifying risk factors of avian infectious disease at household level in Poyang Lake region, China. Prev. Vet. Med. 2014, 116: 151-160.

66. Pacheco, I.C.S, Carvalho, A.M.A, Pontes, E.R.J.C., Silva, M.G. Relationship between climate and dengue incidence in the city of Campo Grande, MS. Multemas. 2017, 22: 235-252.

67. Miyazaki, R. D., Ribeiro, A. L. M., Pignatti, M. G., Campelo Júnior, J. H., Pignati, M. Monitoring of Aedesa egypit mosquitoes(Linnaeus,1762) (Diptera:Culicidae) by means ofovitraps at the Universidade Federal de Mato Grosso Campus, Cuiabá, State of Mato Grosso. Rev. Soc. Bras. Med. Trop. 2009, 42: 392-397.

68. Monteiro, E.S.C., Coelho, M.E., Cunha, I.S., Cavalcante, M.A.S., Carvalho, F.A.A. Aspectos epidemiológicos e vetoriais da dengue na cidade de Teresina, Piauí, Brasil, 2002 a 2006. Epidemiol. Serv. Saúde. 2009, 18: 365374.

69. Fernandes, R.S., Neves, S.M.A.S., Souza, C. K. J., Galvanin, E.A.S., Neves, R.J. Clima e casos de dengue em Tangará da Serra/MT. Hygeia, 2012, 8:78-88.

70. Antônio, G., Silva, C. M., Peder, D. L. Influência das alterações climáticas nos casos de dengue nos anos de 2007 a 2011 no município de Cascavel-PR. SaBios- Rev. Saúde e Bio., 2015, 10:6-14.

71. Freitas, R. M., Peres, R. C., Souza-Santos, R., Lourenço, R. O. Occurrence, productvity and spaal distribuon of key-premises in two dengue endemic areas of Rio de Janeiro and their role in adult Aedes aegypty spatial infestion pattern. Trop. Med. \& Int. Health. 2008, 13:1488-1494.

72. Santos, D.A.S., Rodrigues, J.Z., Olinda, R.A., Goulart, L.S. Relations of climate variables with the cases of dengue interior municipality of Mato Grosso state from the years 2001 to 2015. Multitemas. 2018, 23: 5-24.

73. Silva, A.M., Silva, R. M., Almeida, C.A.P.,Chaves, J. J. S. Modelagem geoestatistica dos casos de dengue e da variação termopluviométrica em João Pessoa, Brasil. Soc. Nat. 2015, 27:157-69.

74. Lima, R.C.M., Elvis Bergue, M., Nóbrega, R.S. A influência climática sobre a epidemia dengue na cidade do Recife por Sistema de Informações Geográficas. Rev. Bras. Geo. Fis. 2016, 9: 384-98.

75. Câmara, F.P., Gomes, A.F., Santos, G.T., Câmara, D.C.P. Clima e epidemias de dengue no Estado do Rio de Janeiro. Rev. Soc. Bras. Med. Trop. 2009, 42:137-40.

76. Brasil. Conselho Nacional de Saúde. Portaria ํo-466/2012.Dispõe sobre diretrizes e normas regulamentadoras de pesquisa com seres humanos. Diário Oficial da União, Brasília, DF,13 de junho de 2013, Seção1,2012, p.59. 
(C2021 by the authors. Submitted for possible open access publication under the terms and conditions of the Creative Commons Attribution (CCBYNC) license(https://creativecommons.org/licenses/by-nc/4.0/). 